\title{
Lamproderma puncticulatum, a new species of Myxomycetes
}

\author{
MARJA HÄRKÖNEN
}

\begin{abstract}
HÄRKÖNEN, M. 1978: Lamproderma puncticulatum, a new species of Myxomycetes. - Karstenia 18: 20-22.

A new species of Myxomycetes, Lamproderma puncticulatum Härkönen, is described from Finland. It has dark brown spots on the peridium and the capillitium is light brown throughout. It was growing on living sporophores of Cantharellus tubaeformis Fr.
\end{abstract}

Marja Härkönen, Department of Botany, University of Helsinki, Unioninkatu 44, SF-00170 Helsinki 17, Finland

\section{Lamproderma puncticulatum Härkönen}

n. $\mathrm{sp}$.

$$
\text { - Figs. } 1-4
$$

Sporangia gregaria, altitudine tota $0.5-1.3 \mathrm{~mm}$. Sporangium globosum, 0.4-0.8 mm diam. Peridium membranaceum, persistens, argenteo-cinereum, iridescens, cum punctis saturate brunneis. Hypothallus discoideus, concolorus peridio. Stipes crassus, altitudine $0-0.5 \mathrm{~mm}$, longitudinaliter sulcatus, concolorus peridio. Columella nigra, truncata, usque ad $1 / 3$ vel ad 1/2 sporangii porrigens. Capillitium pallide brunneum, ramificans, anastomosans. Sporae universae saturate cupreaceobrunneae, luce transmissa purpureo-brunneae, verruculosae, 12.5-13.2-14 um diam. Plasmodium ignotum.

Holotypus: Finlandia, prov. Uusimaa, par. Espoo, ad Cantharellum tubaeformiem, 3.X.1974 M. Korhonen, in Museo Botanico Universitatis Helsingiensis $(\mathrm{H})$ asservatur.

Sporangia gregarious, globose, short-stipitate, total height $0.5-1.3 \mathrm{~mm}$. Head of sporangium $0.4-0.8 \mathrm{~mm}$. Peridium membranous, rough, persistent, irregularly splitting; dark silvery grey (according to Maerz \& Paul 1950, Gunmetal 48 C 2) to the naked eye, under the dissecting microscope iridescent with blue, gold, green and red, and having dark brown, non-iridescent depressions. Stalk $0-0.5 \mathrm{~mm}$ high, thick, furrowed, concolorous with peridium. Hypothallus strong, discoid, concolorous with peridium and partially merging with adjacent hypothalli.
Columella black, robust, cylindrical, extending through about $1 / 3-1 / 2$ of sporangium. Capillitium arising from apex of columella, light brown throughout, dividing and anastomosing and with many free ends. Thickness of threads $3-8 \mu \mathrm{m}$ at base, less than $3 \mu \mathrm{m}$ at apex. Spores globose, dark brown in mass, purple brown in transmitted light, spinulose, $12.5-13.2-14 \mu \mathrm{m}$ in diam. Plasmodium unknown.

Type: Finland. Uusimaa, Espoo: Myllykylä at altitude of less than $50 \mathrm{~m}$, in coniferous forest on living sporophores of Cantharellus tubaeformis Fr., 3.X.1974 Mauri Korhonen ( $\mathrm{H}$ holotype, TEX isotype).

In October 1974 Mir. M. Korhonen, conservator of the Botanical Museum of the University of Helsinki, brought me two sporophores of Cantharellus tubaeformis with bluish shining slime mold sporangia on them. The sporangia clearly belonged to the genus Lamproderma, having a persistent iridescent peridium and the capillitium arising from the apex of the columella (Dennison 1945a, b, NannengaBremekamp 1967, Kowalski 1968). During the past three years, the originally bluish tint of the sporangia has gradually turned more greyish. Under the dissecting microscope the peridium is seen to have brown spots. Kowalski (1970) recognizes four species of Lamproderma having the peridium with dark brown depressions: L. griseum Thind \& Lakhanpal, L. gulielmae Meylan, L. maculatum Kowalski and L. echinosporum Meylan, all exclusively montane in distribution. $L$. maculatum and $L$. echinosporum differ from the present specimen in 

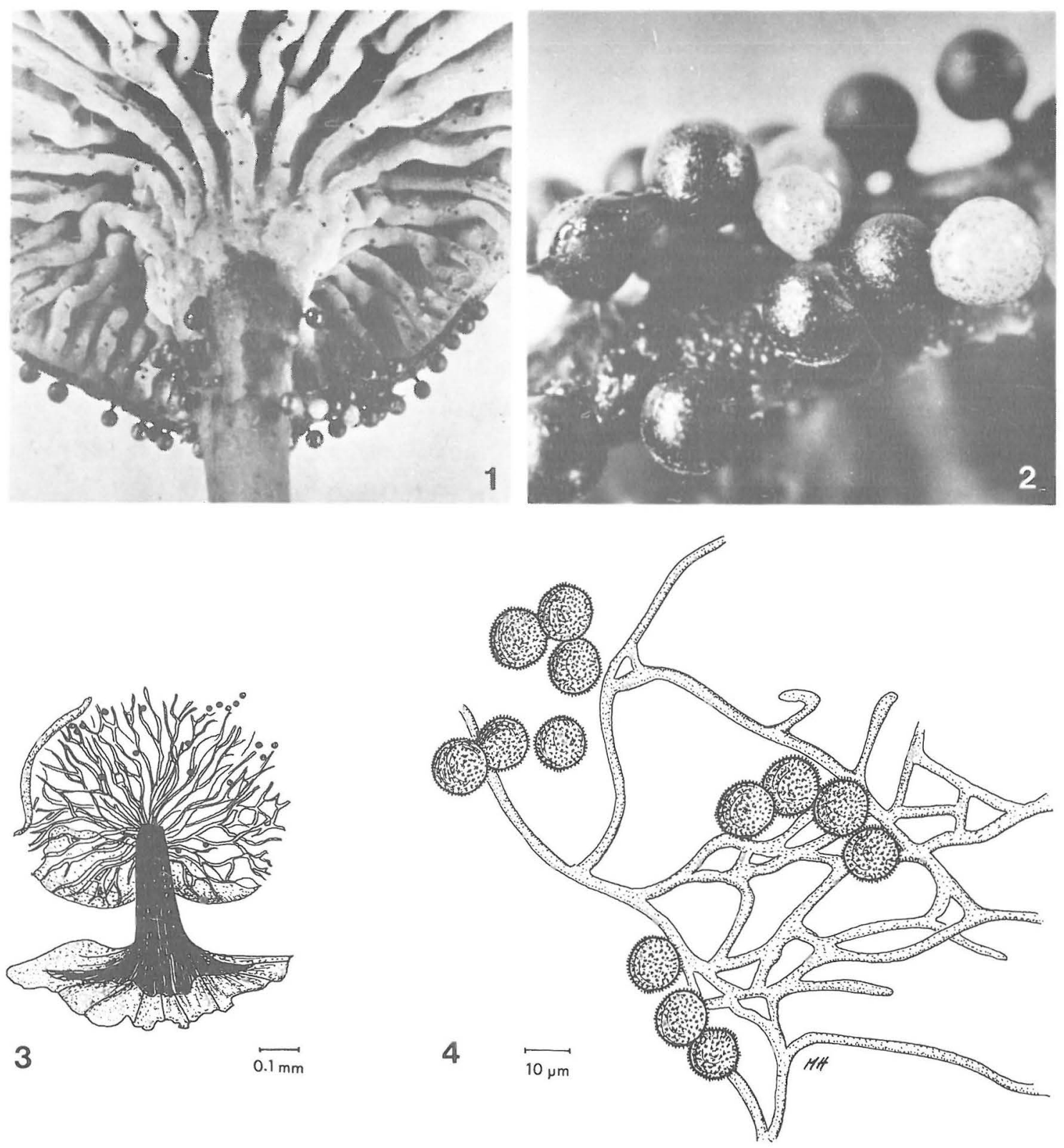

Figs. 1-4. Lamproderma puncticulatum. - 1: On Cantharellus tubaeformis, $\times 4$. -2 : Maturating sporangia, $\times 22$. Photo M. Korhonen. - 3: A sporangium in transmitted light. - 4: Capillitium and spores.

having larger sporangia, over $1 \mathrm{~mm}$ in diam. and a dark brown capillitium. L. griseum is distinguished by peculiar morchelloid reticulate ridges on the peridium, a long stalk and a capillitium that is violaceous with paler bases and apices. The nearest species, L. gulielmae (Meylan 1919, type: Switzerland: Jura Mts.; LAU), differs from the present specimen in the following main characters: The stalk of $L$. gulielmae is longer and thinner, the spots on the peridium are larger, the capillitium is still paler and the spores are strongly echinulate.

So the present specimen clearly belongs to a new species, whose distinctive characteristics are the silvery grey peridium with small dark brown spots, 
relatively short and thick stipe, entirely light brown capillitium and purple brown spinulose spores.

I tested the viability of the spores of the specimen (see Kalyanasundram 1974) by cultivating them in hanging drops (Smart 1937). Many swarm cells developed, but after transfer to different agar plates (Howard 1931, Indira 1969), they failed to produce plasmodia. The plasmodium of the species is thus unknown, but a clue to its colour was obtained, as the sporangia included some immature ones (Fig. 2), which were milky white with brown spots.

Acknowledgement. - I want to thank Professor C.J. Alexopoulos for looking at the specimen, and also for showing it to Dr. D.T. Kowalski and encouraging me to describe it.

\section{References}

Dennison, M. 1945a: The genus Lamproderma and its relationships 1. - Mycologia 37: 80-108.

- " -1945b: The genus Lamproderma and its relationships 2. - Mycologia 37: 197-204.

Howard, F. 1931: Laboratory cultivation of myxomycete plasmodia. - Am. J. Bot. 18: 624-628.

Indira, P. 1969: In vitro cultivation of some Myxomycetes. - Nova Hedwigia 18: 627-636.

Kalyanasundram, I. 1974: Laboratory cultivation of Lamproderma scintillans. - Mycologia 66: 888-892.

Kowalski, D. 1968: Observations on the genus Lamproderma. - Mycologia 60: 756-768.

- »-1970: The species of Lamproderma. - Mycologia 62:
$621-672$

Maerz, A. \& Paul, M. 1950: Dictionary of color. 2nd ed. -208 pp. New York.

Meylan, C. 1919: Notes sur quelques espèces de Myxomycètes. - Bull. Soc. Vaudoise Sc. Nat. 52: 447-450.

Nannenga-Bremekamp, N. 1967: Notes on Myxomycetes 12. A revision of the Stemonitales. - Proc. Koninkl. Nederl. Akad. Wetenschappen (C) 70: 201-216.

Smart, R. 1937: Influence of certain external factors on spore germination in the Myxomycetes. - Am. J. Bot. 14: $145-159$

Thind, K. \& Lakhanpal, T. 1968: The Myxomycetes of India 22. - Mycologia 60: 1080-1085.

Accepted for publication

on October 3, 1977 